\title{
Belgeo
}

Revue belge de géographie

$4 \mid 2003$

The dynamics of metropolisation : from words to territory

\section{J. Agnew, Making political geography}

London, Arnold, 2002

\section{Julien Vandeburie}

\section{OpenEdition}

Journals

Electronic version

URL: http://journals.openedition.org/belgeo/16728

DOI: 10.4000/belgeo.16728

ISSN: 2294-9135

Publisher:

National Committee of Geography of Belgium, Société Royale Belge de Géographie

Printed version

Date of publication: 30 December 2003

ISSN: $1377-2368$

\section{Electronic reference}

Julien Vandeburie, « J. Agnew, Making political geography », Belgeo [Online], 4 | 2003, Online since 14

February 2016, connection on 22 September 2020. URL : http://journals.openedition.org/belgeo/

16728 ; DOI : https://doi.org/10.4000/belgeo.16728

This text was automatically generated on 22 September 2020.

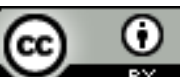

Belgeo est mis à disposition selon les termes de la licence Creative Commons Attribution 4.0 International. 


\title{
J. Agnew, Making political geography
}

\author{
London, Arnold, 2002
}

Julien Vandeburie

\section{REFERENCES}

\section{J. Agnew, Making political geography, London, Arnold}

1 This book is an interesting introduction to political geography. The author gives a good idea of what political geography used to be, what it is and what it will be.

2 First, he discusses the terms of political geography : Politics and place ? Geopolitics ?... Finally, political geography is always the meeting point of geography and politics.

In a second step, Agnew explains the history of the thinkers in political geography, from the French and the German school to the postmodernist wave, with comments about the English school, Bowman, Gottman amongst others. Then he demonstrates, with the help of what he calls "vignettes ", why political geography still matters. The vignettes are interesting examples illustrating issues such as drug trafficking, the Israeli-Palestinian conflict, sub-Carpathian Ruthenia, the representation of nations in stamps, urban problems in south-central Los Angeles...

In chapter 3, Agnew discusses what he calls the historic canon, the geopolitical context of the foundation of political geography. Even if he has a really interesting point of view about very old influences, it is surprising that we do not read anything about Mahan's or Monroe's influence. Another remark concerns the relative lack of maps in this chapter.

5 Chapter 4 is devoted to the revival of the discipline after a fade-out during the domination of behaviorist and quantitative currents.

6 Chapter 5, The Horizon, deals with the new ways of analysis of political geography. Agnew distinguishes three main groups: 1) what he calls geographical scale, which includes electoral geography, 2) politics of environment, 3) normative political geography, which contains questions about democracy. 
7 As a conclusion, a good book to guide students in the study of political geography, or to explore this field of geography. Agnew's non-state centred analysis is particularly interesting, and so are the parts devoted to national elections, and regional perspectives. 